\title{
Racism Against Asian During the Covid-19 Pandemic
}

\author{
Siti Kofifah ${ }^{111}$, Ariya Jati $^{2}$ \\ ${ }^{1}$ Department of English, Faculty of Humanities Dioponegoro University Semarang - Indonesia, \\ ${ }^{2}$ Department of English, Faculty of Humanities Dioponegoro University Semarang - Indonesia,
}

\begin{abstract}
Covid-19 was discovered in Wuhan China on December $1^{\text {st }}$, 2019. On March $9^{\text {th }}, 2020$, WHO (World Health Organization) officially announced Covid-19 as a pandemic. Since the declaration of Covid-19 as a global pandemic, Covid-19 causes a major impact in various fields. Starting from the economy, education, to human resources.The most significant is felt by Asians or people with Asian ethnicity. They start to receive racist treatment starting hate comment on social media, insults, or bad treatment from others towards them. This paper is aimed to discuss the background to the emergence of racism against Asian during the Covid-19 pandemic and its impact, especially in America. The method used is data collection taken from news and journal articles related to racism and Covid-19. The result is how Covid-19 can trigger racism against Asian in America and the form of racism and its impact to Asian in America. In conclution, some factors, such as governments that tend to be racist, the pre-existing xenophobic and exclusive government environment exacerbates the negative stigma in society. Various forms of racism starting from hate speech on social media, verbal attacks to physical violence. Racism has caused mental problems for Asian Americans, such as anxiety, depression and lack of confidence to their identity as Americans.
\end{abstract}

\section{Introduction}

Covid-19 was discovered in Wuhan, China, on December 1 2019. This virus spread quickly, and the Chinese government at that time immediately closed the city of Wuhan and isolated the people in it in order to stop the transmission of covid-19. Covid-19 is actually not a new virus. This virus is a family with the type of coronavirus that caused SARS in 2003. This virus is then named Respiratory Syndrome Coronavirus 2 (SARSCOV2), which causes Corona Virus Disease-19 (Covid-19).

Because of its rapid spread and easy mode of transmission, Covid-19 has spread rapidly in almost all countries around the world. Related to it, finally, on March 9, 2020, the WHO (World Health Organization) officially announced Covid-19 as a pandemic. The spread of

\footnotetext{
*Corresponding author: fifahfifah03@gmail.com, ariya.jati@live.undip.ac.id
} 
covid-19 has a negative impact in various fields. Starting from an economic field, education to human resources. In terms of human resources, the most significant impact is felt by Asians or Asian ethnicities. They begin to get bad treatment, ranging from hate comments on social media, insults to being harassed physically. Many studies have examined racism against Asians, especially during this pandemic. The emergence of Covid -19 , which is known to have been discovered for the first time in China's Wuhan, has contributed to the increase in unpleasant incidents experienced by Chinese and Asian groups on a large scale. [1]. According to recent The Asian Pacific Policy and Planning Council and Chinese for Affirmative Action organization surveys, Covid-19 has sparked 1,497 incidents of hatred with race as the reason behind the incident [8]. In addition, a warning of the potential for an increase in Anti-Asian crimes against the backdrop of Covid-19 has been issued by the FBI [8]. Recent reports indicate a surge in prejudice and discrimination against Asians in America that has been linked to Covid-19. [6].

The researches show that racism and xenophobia spiked at the same time with the Covid-19 pandemic or during the Covid-19 pandemic. [5]. As an example in this case, based on reports received by The Asian Pacific Policy and Planning Council, out of 1800 reports of discrimination received by Asians during this pandemic, there are AsianAmericans who received physical assault, verbal abuse, eviction in shops. and restaurants, discrimination at work, and subject to properly vandalism.[1]. There is also research that examines the impact Asian people have on education as well as the psychological impact on Asians.

A lot of research discusses the same background topic, such as how the Covid-19 pandemic is related to the issue of racism that occurs to Asians. There are several journals that have similarities in the setting in which the problem arises. Most of them discuss racism against Asians in the USA. Some journals also have some discussion about how the coronavirus started. Several journals also have similarities in discussing how people are starting to have a negative stigma against Asians and how the coronavirus causes xenophobia; However, there is a lack of detailed research related to the background and forms of racism aimed at Asians in existing research, it is usually studied only about its impact, and few have examined the background, the form of racism that is accepted to the wider impact. This article is aimed to discuss the background to the emergence of racism against Asian during the Covid-19 pandemic and its impact to the Asian.

We also examine what impact Asians have on racism that they accept more broadly. This issue is important to study to provide the fact that a disease could have a major impact on the group life sustainability. In addition, it is expected that people would be more aware that there are groups that need their support because they do not deserve to be mistreated for things that happen against their will.

This research used data collection taken from news and journal articles related to racism and Covid-19. We gathered some information from the researchers included in the journal article and cases from the news. Some theories might also include. It aimed to give more detailed information about the background of racism towards Asians and the form of the racism itself during the Covid-19 Pandemic.

\section{Method}

This this research used data collection taken from news and journal articles related to racism and Covid-19. We gathered some information from the researchers included in the journal article and cases from the news. Some theories might also include. It aimed to give more detailed information about the background of racism towards Asians and what impact they have to face. We try to process information in journal articles and some of the news for later analysis and conclude so as to produce more detailed information about the topic we are studying. 


\section{Result}

\subsection{The background of the emergence of racism against Asian-Americans or Asian races in America}

The increase in racism against Asians in America is due to various factors. Covid-19 is the main reason behind the increase in racist crimes that occurred during the Covid-19 pandemic. This is related to Covid-19, which was first discovered in Wuhan, China, which has resulted in a bad stigma on Chinese people and other Asian people. Apart from that, the government's attitude, which tends to blame China by saying that the Coronavirus is a "Chinese virus", also exacerbates the stigma against Asians. Another factor comes from an exclusive government environment which gives rise to an exclusive nationalism. In addition, the existence of xenophobia which is an attitude of anti or fear of outside culture, also influences. Because Covid-19 is a virus that is found in China, this is enough to lead to a negative stigma against culture in China, which is a country in Asia, which in the end, is aimed at Asian people outside of China.

\subsection{Forms of Racism against Asian-Americans / Asians in America during the Covid-19}

The forms of racism accepted by Asian-Americans or Asians include verbal blasphemy, hate comments on social media, evictions from shops or restaurants, discrimination in the work environment and being the target of property vandalism. Even in the latest news reports of violence that led to death received by Asians in America who are motivated by their ethnicity in connection with the Covid-19 pandemic.

\subsection{Impact on Asian/Asian Americans}

The impact felt by Asian/Asian-Americans due to the racism they experience is that they have to deal with mental health problems. Massive trauma due to a pandemic can trigger mental health problems such as anxiety, depression. The growing phenomenon of antiAsian racism during the Covid-19 pandemic has had an impact on the mental health of Asian Americans. They experience traumatic stress because of their race, and the stereotype that they are enemies causes a health crisis for them. In addition, they also become less confident in their appearance and doubt their identity as American citizens.

\section{Discussion}

Since the Since the Covid-19 outbreak, Asian Americans have been more likely to feel targeted by racism. The Asia Pacific Policy and Planning Council has also set up a Center called Asians Americans and Pacific Islanders (AAPI) to report discrimination. The outbreak of the Covid-19 pandemic, which was first discovered in Wuhan, China, is the reason behind the increase in racist crimes against Asian-Americans or the Asian race. According to data from the New York City Police Department (NYPD), there were 29 attacks based on racial factors against Asian-Americans in New York City and as many as 24 cases were driven by the Coronavirus Xenophobia that arises against Asians even occurs among government officials. [3]. Former President Donald Trump has also mentioned Covid-19 as the "Chinese virus". This has contributed to increased racism against Asians or bad sentiment towards Asians, especially in America. It started in mid-March when 
President Trump called the coronavirus the 'Chinese virus' on Twitter, resulting in a high spike of dangerous fake news about the spread of the virus and anti-Chinese racism. The use of anti-china statements by the president has led to right-wing nationalism and provoked an act of racial discrimination against Chinese-Americans. Discrimination against Chinese ethnicity is likely to continue as a result of the Covid-19 pandemic, which will not disappear in a short time, as well as the bad effects of the pandemic that will last a long time. Covid-19 is closely related to racism and xenophobia for two fundamental reasons. First, Covid-19 has contributed to an increase in bad sentiment towards minority communities, the second, this pandemic has also emerged in an environment of the exclusive nationalist government, which further exacerbates xenophobia and racism towards Asians. The first reason shows the indirect social side of the national and global emergency. A pandemic is a deadly natural disaster and is a global health emergency with a major impact on human life. [5]. A pandemic can risk causing sharp economic turmoil that will affect the world's population at large. The increase in racism and xenophobia in the increase of exclusive nationalism is often caused by a depressive socio-economic environment [5]. This assumption is evident during the current Covid-19 pandemic [5]. The Stigma term was introduced by Goffman refers to the observable characteristics of a person that cause society to judge them as unfit to enter the mainstream of society. The current COVID-19 stigma can be interpreted as a social process that defines and excludes people who are considered to be potential sources of disease and a threat to effective social life in society. Becker's theory states that people label other people to facilitate their understanding of the social environment around them. This theory shows stigmatization as something that happens to people who are labelled as deviant based on their specific behaviour that is judged to be contrary to acceptable standards. By the socio-cultural framework resulted in the attachment of stereotypes to the label of storing and the target of receiving negative psychosocial and emotional reactions from society.

The stigma against Asia has increased since the emergence of the COVID-19 pandemic. More than 1,800 reports of discrimination experienced by Asian-Americans have arrived at the Asia Pacific Policy and Planning Council within eight weeks. [1]. As many as 39\% of Asian people and $38 \%$ of black adult people, up to $27 \%$ of Hispanic adults said that they received unpleasant behaviour based on their race and ethnicity during the Covid-19 pandemic. Whereas for white people, there are only 13\% of acts of racism they accept. [9].For instance are physical assaults of Asian Americans, verbal harassment, expulsion from shops and restaurants, discrimination in employment, and targets for property vandalism. Xenophobia insists Asian-Americans return to their origin countries, which is a form of exclusion of Asian-Americans as foreigners (remain to be foreigners) even though they are US citizens and descent. [4]. Data from Stop AAPI Hate shows that there were around 500 incidents in the first two months of 2021. The number could increase again to reach 3,795 complaints when measured in the last year. It was reported that $68 \%$ was in the form of verbal abuse and $11 \%$ was in the form of physical abuse. Recently reported shootings and murders in a spa area in Atlanta on Tuesday (16/3/2021) local time, carried out by Americans with at least eight victims and 6 of them Asian-American women. There have also been reports of deaths recently, with some of the victims being Asian in America. One of them is the murder incident of an immigrant from Thailand, Vichar Ratanapakdee. Not only that but it was also reported that there was a brutal assault on a 67-year-old man in San Francisco. Another case is the beating suffered by a man named Denny Kim in Koreatown Los Angeles. Not only that, but the attacker also shouted at him as having the Chinese Virus and shouted at him to return to China. 
Existing research into massive trauma and disease outbreaks indicate a possible spike in mental health problems such as anxiety, depression and drug abuse, as well as subclinical stress responses such as anger, fear, and sleep disturbances. This may last for several months or several years [1]. It is feared that this mental health vulnerability for Asian Americans could be exacerbated by Anti-Asian Covid-19. The politicization of the pandemic and the scapegoat that can be in the form of propaganda can result in alienation and have a negative impact in the long term (Z. Chen et al., 2008) and can lead to an increase in suicidal thoughts [1]. In addition, Asian Americans may experience traumatic stress from being associated with race [1]. They are labelled as enemies and are considered to be the cause of a national health crisis. Taxes were also imposed on them, and they also received anti-Asian verbal and physical attacks [1]. The negative impact Asian Americans will have on their xenophobia and anti-Asian racism on their mental health and selfconfidence, and identity as Americans, particularly among teenagers and adults. Examples of evidence indicating increased experiences of racism (e.g. discrimination) are associated with lower self-esteem measures, especially for young people.[1]. In addition, Xenophobic exclusion of Asian-Americans can lead to increased self-awareness, dissatisfaction and embarrassment among Asian-Americans with their body image. One study showed a greater degree of experience of racism (e.g. discrimination, racial jokes, constant labelling of strangers) was associated with increased body image anxiety in young, Asian-American adults. [1].

\section{Conclusion}

Since the Covid-19 outbreak, Asian Americans have been more likely to feel targeted by racism. As previously explained, the origin of the discovery of Covid-19 is the main reason behind the increasing racism against Asian ethnicities in America. However, the emergence of Covid-19 from China is not the only factor behind acts of racism in America. Other factors, such as governments that tend to be racist, also contribute to the negative stigma in society regarding the place where this virus was first discovered, which then has a negative impact on people who come from that area, namely China, which is a country in Asia, so the stigma is negative. To a wider area that is not only aimed at China but also for other ethnic Asian people. The pre-existing xenophobic and exclusive government environment also exacerbates the negative stigma in society. Accepted forms of racism vary considerably. They are starting from hate speech on social media, verbal attacks, to physical violence. Apart from that, racism has caused mental problems for Asian Americans; they have to suffer from mental health problems such as anxiety, depression and lack of confidence in their bodies to their identity as Americans. We have even seen in the previous discussion that the crime of racism can result in the loss of a person's life. This shows that the emergence of an epidemic can be very influential in the life of an ethnic group. Regardless of the origin in which an outbreak is found, external factors such as the environment in which the plague spreads and the people within it are involved in converting a disease into a threat from a particular ethnicity. Of course, this is very unfortunate, and there is a need for more education for the public regarding this matter.

\section{Reference}

1. 1. Xenophobia and Racism Against Asian Americans During the Covid-19 Pandemic: Mental Health Implication. Cheng, Hsiu-Lan. 2020, Vol. 3. 
2. 2. Stigma and Discrimination During. Divya Bhanot1, Tushar Singh2*, Sunil K. Verma3 and Shivantika Sharad3. (2021)

3. 3. Asian-Americans and Pacific Islanders in COVID-19:. Daniel Wang, MD1, Gilbert C. Gee, PhD2, Ehete Bahiru, MD3, Eric H. Yang, MD3, and. J Gen Intern Med, p. 3687. (2020)

4. 4. Asian and Asian American CollegeStudents' Educational and Career Dilemmas. JIANG, SHANSHAN. (2020)

5. 5. Racism and nationalism during and beyond the Covid-19 Pandemic. Amanuel Elias, Jehonathan Ben, Fethi Mansouri \& Yin Paradies. Vol.. 44 (2021)

6. 6. Exploring U.S. Shifts in Anti-Asian Sentiment withthe Emergence of COVID-19. (2020)

7. 7. Asian-Americans and Pacific Islanders in COVID-19:Emerging Disparities Amid Discrimination. Daniel Wang, MD1, Gilbert C. Gee, PhD2, Ehete Bahiru, MD3, Eric H. Yang, MD3, and. (2020)

8. 8. Racism is a Virus : Anti Asian Hate and Counterhate in Social Media during the Covid 19 Crisis. Caleb Ziems, Bing He, Sandeep Soni, Srijan Kumar. (2020)

9. 9. Many Black and Asian Americans Say They Have Experienced Discrimination Amid the COVID-19 Outbrea. Neil G. Ruiz, Juliana Horowitz and Christine Tamir. 2020.

10. Thea Fathanah Arbar, CNBC Indonesia." Heboh Anti-Asia di Amerika, Ini 'Biang Kerok' Penyebabnya" https://www.cnbcindonesia.com/news/20210323111516-4232142/heboh-anti-asia-di-amerika-ini-biang-kerok-penyebabnya 